\title{
Budgeting Analysis Model: Gender as a Moderating Variable In Manufacturing Companies in East Java
}

\author{
Dwi Suhartini ${ }^{1}$, Hero Priono ${ }^{2}$, Astrini Aning Widoretno ${ }^{3}$ Saiful Anwar ${ }^{4}$ Fajar Syaiful \\ $\mathrm{Akbar}^{5}$, \\ \{ suhartinidwi7@gmail.com¹,titukdiahwidayantie@gmail.com² ${ }^{2}$,astrini.widoretno.ak@upnjatim.ac.id ${ }^{3}$ \\ saifulupn@gmail.com ${ }^{4}$, fajar.akbar.ak@upnjatim.ac.id ${ }^{5}$ \} \\ 1,2,3,4,5 UPN Veteran Jawa Timurt, Raya Rungkut Madya Street, Surabaya, Indonesia
}

\begin{abstract}
Budgeting is one of the most important tools to facilitate management tasks in achieving organizational goals, especially in responding to the challenges of the Asean Economic Community. However, companies are not able to achieve organizational goals when there are deviations of human behavior involved in budgeting and will have an impact on the company's poor performance. The purpose of this study is to examine and analyze the effect of participatory budgeting on gender-moderated dysfunctional behavior. This research uses quota sampling technique with survey method. The data collected was 128 questionnaires. The analysis unit used was the functional manager of a manufacturing company in East Java. Technical analysis using PLS. The results showed that participatory budgeting can reduce dysfunctional behavior. The role of gender as a prediction in reducing dysfunctional behavior. Female managers have not been shown to behave more ethically in preparing budgets. The contribution of this research is to enrich behavioral accounting knowledge in management accounting studies, and also to give discourse to business people that the empowerment of psychological aspects can reduce dysfunctional behavior in participatory budgeting
\end{abstract}

Keywords: Participative Budgeting. Dysfunctional Behavior, Gender

\section{Introduction}

Budgeting is one of the main management tools are essential to facilitate management tasks to achieve organizational goals, especially the challenge of the Asean Economic Community (AEC). Nevertheless, the organization's goals will not be achieved when there is a deviation of human behavior that are involved in partisipative budgeting and adversely affects the performance of the company. Partisipative budgeting in addition to having a positive impact also have potential problems, in case of pseudo participation which can lead to dysfunctional behavior (Mowen et al., 2014: 404).

Pseudo participation can lead to disappointment and in turn reduces the commitment in the achievement of the budget (Nahartyo, 2013). Dysfunctional behavior also caused no violation of the psychological contract in the budgeting process, so as to reduce the honesty in presenting the information in the budget (Krishnan, 2012). Potential behavior problems in partisipative budgeting has the potential to degrade performance. One form of dysfunctional behavior in budgeting and extensively studied is the budgetary slack. 
According to Husain (2011), budgetary slack is dysfunctional behavior unethical managers and slack resulted in a waste of resources manager although provide protection from unexpected economic changes (Langevin and Mendoza, 2013). Agree, Otley in Belkoui (1989: 58) states that the concept of budgetary slack there are positive and negative. Positive action indicates conservative managers in the face of uncertainty in the preparation of the budget, while the negative ones indicate a personal interest in the preparation of the budget, and in practice often encountered negative budgetary slack. Apriwandi (2012) and Suhartini et al. (2015) proved that partisipative budgeting improve managerial performance through budgetary slack behavior.This condition is triggered by the actions of managers in the face of high uncertainty of business environment in order to maintain their managerial performance.

Libby and Lindsay (2007) provides an example of the negative forms of dysfunctional behavior, like the behavior of managers make high sales target information without knowing the reputation of the debtor company and the actions of managers purposely moved a number of profit the following year when the profit target for the year was exceeded. Thus, the performance reports do not reflect the actual conditions and this behavior may endanger the sustainability of the company in the long term.

Nahartyo (2013) states that the partisipative budgeting creates behavioral problems and an accountant can not ignore the behavioral sciences, because the decision-making functions of accounting is a function of the behavior (Carter and Usry, 2002: 1-9). Based on these opinions can be concluded that when talking about the budgeting process does not only focus on the magnitude of the numbers in the budget, but to consider the psychological aspects that characterize personal manager. Furthermore, aspects such behavior can affect the performance of individuals and the wider may affect the company's performance. Personal character of which is variable gender.

Research the topic of gender in Indonesia showed a response which is still low compared with other topics (Nurhaeni, 2010: 10). To that end, the study of gender relations in the organization and management is considered a logical and important to investigate (Broadbridge and Hearn, 2008). Likewise, Robbins and Judge (2013: 46) states that only a few issues to discuss debate about differences in work performance between female and male. Indonesia adheres to a patriarchal culture by positioning female as marginalized as it is proved that female occupy managerial composition in Indonesia is still low. This is consistent with the findings of Bakrie (2012) states that there are only six per cent of female in Indonesia who managed to sit at the level of directors and six percent occupied CEO level, (http://regional.kompas.com/read/2012/09/17/02081143)

Previous research has been no linking gender with partisipative budgeting and dysfunctional behavior-behavior disfungsional- information manipulation and gaming. However, that revealed no gender differences in the context of the decision makers showed mixed results, as Kmec and Gorman (2010) proved that there No gender differences in the workplace in the United States. And SukiSuki (2011) explains that there are no differences in gender roles on job satisfaction and organizational commitment to the managers in the financial services sector in Malaysia.

However, some studies found evidence that female act more ethical than male. O'Fallon and Butterfield (2005) questioned the truth that female are more ethical than male in the decisionmaking context. Akers and Eaton (2003) proved that female have a perception auditor audit dysfunctional behavior is higher than male auditors. Bampton and Maclagan (2009) reveals that female are more ethical business decision making than male. Gulzar and Wang (2011) found that female directors are unlikely to make profit management. Yuhertiana (2011) found that the head of female are more ethical than male heads of agencies in formulating their budgets in East Java.

Results of previous studies also give ambiguous results when connecting directly partisipative budgeting with dysfunctional behavior, such as Soobaroyen (2007) proved that partisipative 
budgeting can reduce dysfunctional behaviors, but instead $\mathrm{Su}$ and Yu-Ni (2013); Breaux et al. (2011) reveal that the partisipative budgeting was not able to improve performance. The ambiguous results of research that is possible can not be measured directly, but through contingency variables that model into a fit.

Based on some of the above results were varied, then there is a chance to enter the variable gender as contingency variables that moderate the relationship of partisipative budgeting with dysfunctional behavior. Agreed, Belkaoui (1989: 96) states that gender can be used as variables moderating the relationship between participative budgeting with performance. In general, the concept of gender is used as independent variables and used as a dichotomous variable of male and female. This study is different, because $\mathrm{v}$ ariabel gender will be measured using several indicators that describe the elements of biological and psychological factors by using the scale interval.

To that end, researchers are interested in examining the effect of the partisipative budgeting with dysfunctional behavior in the manufacturing companies in East Java directly or indirectly through moderating variables of gender and also whether female are more ethical managers than male managers in preparing the budget. This study aims to examine and analyze the relationship between the partisipative budgeting with dysfunctional behavior directly or indirectly through the variables of gender, and to analyze whether female managers behave more ethically than male managers in preparing the budget.

\section{Research Method}

\section{Data Collection and Sample Determination}

This research was conducted in manufacturing companies in East Java, the reason being that the performance of manufacturing companies in East Java in 2012 ranked third on export performance after DKI Jakarta and East Kalimantan by contributing 10.04\% (Industry Magazine, 2013). Data collection uses mail survey, both sent directly to the respondent's address, e-mail and survey staff. The target population of the study was the manager function that works on medium and large manufacturing companies in the province of East Java . Consideration of using medium and large scale companies because the activities in the budget process are complex .

The sampling technique uses quota sampling. Sugiyono (2017: 63) explains that quota sampling is a technique for determining samples from populations that have certain characteristics until the desired amount (quota) is fulfilled. the special characteristics of the respondents used as samples are the manager of women and men who work in medium and large manufacturing companies in the province of East Java, were actively involved in the drafting team and a minimal budget already worked at least 2 years. Hair et al. (2010: 102) suggest that the appropriate sample size ranges from 100-200 respondents, and in accordance with the analysis techniques used using PLS is sufficient to represent the population.

\section{Result and Discussion}

\section{Overview of Respondents}

Based on the results of data collection, there are 128 data questionnaires that can be processed and analyzed. The amount of data has fulfilled the requirements of the PLS technical analysis. Respondents who filled out the questionnaire were mostly filled by financial managers and production managers, while in terms of gender many were dominated by male managers. For that, more details can be seen in table 1. Profile of respondents can be seen in Table 1. 
Table 1

Respondent demographics

\begin{tabular}{lll}
\hline $\begin{array}{l}\text { Profile of } \\
\text { Specification }\end{array}$ & Number of people) & Percentage (\%) \\
\hline Gender & & \\
Female & 44 & $34 \%$ \\
Male & 84 & $66 \%$ \\
Age & & \\
$25-35$ & 25 & $20 \%$ \\
$36-46$ & 58 & $45 \%$ \\
$47-57$ & 44 & $34 \%$ \\
$\geq 58$ & 1 & $1 \%$ \\
Education & & \\
High School & 2 & $2 \%$ \\
D1-D4 & 4 & $3 \%$ \\
S1 & 104 & $81 \%$ \\
S2 & 18 & $14 \%$ \\
Office & & \\
Finance Manager & 40 & $31 \%$ \\
Purchasing manager & 8 & $6 \%$ \\
Production manager & 33 & $26 \%$ \\
Marketing Manager & 22 & $17 \%$ \\
Personnel manager & 19 & $15 \%$ \\
& & $5 \%$ \\
Operational manager & 60 & $5 \%$ \\
Years of service & 12 & \\
$2-5$ th & 7 & \\
$6-10$ th & & \\
$11-15$ th & & \\
$\geq 16$ th & & \\
\hline
\end{tabular}

\section{Hypothesis 1 and 2}

Test Indicators ( Measurement Model )

Based on the model there are indicators outer declared invalid namely Gender G1,4,6 and PD2 dysfunctional behavior is due to loading it under 0:50. As for the test composite Reliability indicates that all variables declared reliable because the value of loading it above 0.70 .

Structural Test (Test of Influence or Hypothesis 1 and 2) coefficient of Determination

The table below shows that the interaction of gender and partisipative budgeting affect low against the dysfunctional behavior that is 0.1559 or $16 \%$. That is, gender is perceived to affect low against dysfunctional behavior.

Table 2.

Overview 


\begin{tabular}{|c|c|c|c|c|c|c|}
\hline & AVE & $\begin{array}{l}\text { composite } \\
\text { Reliability }\end{array}$ & R Square & $\begin{array}{l}\text { Cronbachs } \\
\text { Alpha }\end{array}$ & Communality & redundancy \\
\hline Gender & 0.508973 & 0.835311 & & 0.78855 & 0.508973 & \\
\hline DB & 0.502184 & 0.85737 & .1559 & 0.802169 & 0.502184 & 0.115968 \\
\hline PB & 0.754215 & 0.938124 & & 0.916027 & 0.754215 & \\
\hline $\begin{array}{l}\text { PB* } \\
\text { Gender }\end{array}$ & 0608931 & 0.974819 & & 0.973996 & 0.608931 & \\
\hline
\end{tabular}

\section{Analysis Total Effect}

The table below shows the gender negatively affect the dysfunctional behavior of -0.779 [TS ${ }_{\text {statistic }} 2,184>\mathrm{T}_{\text {Table }} 1.96$ ] means that the higher the gender roles of dysfunctional behavior decreases. Pengaggaranpartisipative significant negative effect on dysfunctional behavior of -0.723

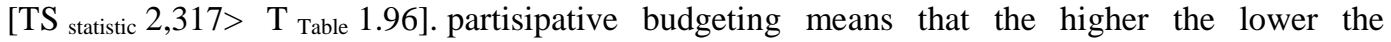
dysfunctional behavior. Interaction with gender partisipative budgeting is not significant positive effect on the dysfunctional behavior of 0,816 [TS statistical $1.740<\mathrm{T}$ Table 1.96]. This means that the higher the partisipative budgeting * gender, the higher the dysfunctional behavior but not significantly. Results of hypothesis testing showed acceptable $\mathrm{H} 1$ and $\mathrm{H} 2$ are not accepted.

Table 3

Total Effects

\begin{tabular}{|c|c|c|c|c|c|}
\hline & $\begin{array}{l}\text { Original } \\
\text { Sample } \\
\text { (O) }\end{array}$ & $\begin{array}{l}\text { Sample } \\
\text { Mean } \\
\text { (M) }\end{array}$ & $\begin{array}{l}\text { Standard } \\
\text { Deviation } \\
\text { (STDEV) }\end{array}$ & $\begin{array}{l}\text { Standard Error } \\
\text { (Sterr) }\end{array}$ & $\begin{array}{l}\text { T Statistics }(\mid \mathrm{O} \\
\text { / Sterr } \mid)\end{array}$ \\
\hline $\begin{array}{l}\text { Gender } \quad-> \\
\text { DB }\end{array}$ & $\begin{array}{c}- \\
0.77967 \\
\end{array}$ & $\begin{array}{c}- \\
0.75564 \\
\end{array}$ & 0.357002 & 0.357002 & 2.183934 \\
\hline $\mathrm{PB}->\mathrm{DB}$ & $\begin{array}{c}- \\
0.72301 \\
\end{array}$ & $\begin{array}{c}- \\
0.63313 \\
\end{array}$ & 0.31194 & 0.31194 & 2.317773 \\
\hline $\begin{array}{l}\text { PB * Gender } \\
\rightarrow>\text { DB }\end{array}$ & .8157 & 0.691444 & 0.468808 & 0.468808 & 1.739946 \\
\hline
\end{tabular}

\section{Hypothesis 3}

\section{Total Effect Analysis Group Female}

The table below shows that the female gender in the group significant negative effect on the dysfunctional behavior of -0.503 [TS statistical $1.203<\mathrm{T}$ Table 1.96 ] means that the higher the gender roles of dysfunctional behavior decreased but not significantly. Partisipatif budgeting significant negative effect on dysfunctional behavior of -0.622 [TS statistical $2.162>\mathrm{T}$ Table 1.96]. Partisipative budgeting means that the higher the lower the dysfunctional behavior. Partisipative budgeting interaction with female gender group no significant positive effect on the dysfunctional behavior

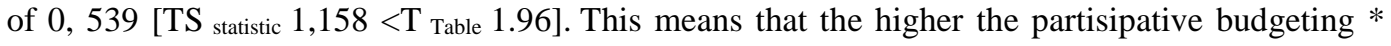
gender, the higher the dysfunctional behavior but not significantly. 
Table 4

Ttotal Effects

\begin{tabular}{|c|c|c|c|c|c|}
\hline & $\begin{array}{l}\text { Original } \\
\text { Sample (O) }\end{array}$ & $\begin{array}{l}\text { Sample } \\
\text { Mean (M) }\end{array}$ & $\begin{array}{l}\text { Standard } \\
\text { Deviation } \\
\text { (STDEV) }\end{array}$ & $\begin{array}{l}\text { Standard Error } \\
\text { (Sterr) }\end{array}$ & $\begin{array}{l}\mathrm{T} \\
\text { Statistics ( } \\
\mathrm{O} / \text { Sterr } \mid)\end{array}$ \\
\hline $\begin{array}{l}\text { G }(\text { Female=F }) \\
\rightarrow \text { DB }\end{array}$ & -0.503009 & 0.401020 & 0.418192 & 0.418192 & 1.202818 \\
\hline PB -> DB & -0.621901 & $\stackrel{-}{-} \cdot 525131$ & 0.287663 & 0.287663 & 2.161913 \\
\hline $\mathrm{PB} * \mathrm{G} F->\mathrm{DB}$ & 0.539937 & 0.383223 & 0.466316 & 0.466316 & 1.157876 \\
\hline
\end{tabular}

Total Effect Analysis Group for Male

The table below shows that the gender on male group significant negative effect on

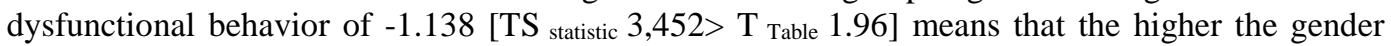
roles dysfunctional behavior decreases. Partisipative budgeting significant negative effect on

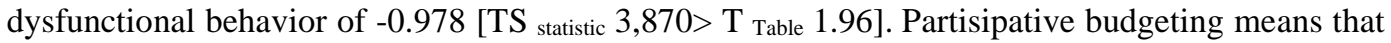
the higher the lower the dysfunctional behavior. Partisipative budgeting interaction with male gender group significant positive effect on dysfunctional behavior amounted to 1.228 [TS statistical 2.819> $\mathrm{T}$ Table 1.96]. This means that the higher the partisipative budgeting * gender, the higher the dysfunctional behavior. The test results showed H3 hypothesis is not accepted.

Table 5

Total Effects

\begin{tabular}{|c|c|c|c|c|c|}
\hline & $\begin{array}{l}\text { Original } \\
\text { Sample } \\
(\mathrm{O})\end{array}$ & $\begin{array}{l}\text { Sample Mean } \\
\text { (M) }\end{array}$ & $\begin{array}{l}\text { Standard } \\
\text { Deviation } \\
\text { (STDEV) }\end{array}$ & $\begin{array}{l}\text { Standard Error } \\
\text { (Sterr) }\end{array}$ & $\begin{array}{l}\mathrm{T} \text { Statistics } \\
(\mid \mathrm{O} / \text { Sterr } \mid)\end{array}$ \\
\hline $\begin{array}{l}\text { G (Male }=M)- \\
>\text { DB }\end{array}$ & $\begin{array}{c}- \\
1.137823\end{array}$ & $\begin{array}{c}- \\
1.064336\end{array}$ & 0.329648 & 0.329648 & 3.451627 \\
\hline $\mathrm{PB}->\mathrm{DB}$ & $\begin{array}{c}- \\
0.977887\end{array}$ & 0.899732 & 0.252670 & 0.252670 & 3.870214 \\
\hline $\mathrm{PB} * \mathrm{GM}->\mathrm{DB}$ & 1.228119 & 1.086896 & 0.435611 & 0.435611 & 2.819300 \\
\hline
\end{tabular}

\section{Hypothesis Testing}

\section{Hypothesis 1 (H1)}

The first hypothesis testing results show that the variables of partisipative budgeting has a significant negative influence on behavior proved dysfunctional. The results of this research has proved that the method of partisipative budgeting is an effective method in formulating the budget. The mechanism of partisipative budgeting will lead to positive communication with each other providing the best information. As a subordinate under manager will reveal information about the center of its responsibilities and provide the best ideas in formulating the budget, while the superior will be committed to not violate the agreement that was made with a subordinate. 
Results of studies have proven the positive impact of partisipative budgeting mechanism can change the mindset and behavior of managers to respond negatively to the perception of dysfunctional behavior. Partisipative budgeting has provided evidence can improve job satisfaction and increased realization of the budget as well as improve performance (Atkinson, 2012:358), punctuated by Yuen (2007) proved that partisipative budgeting has positive influence on the attitude of the manager involved.

Respondents have the perception that partisipative budgeting has provided some benefits to an organization, such as the exchange of information that can be used to improve decision making and continue communication and coordination. This condition allows East Java is known as an industrial city that is growing quite well, even exceeding the national rate of growth of industrial production (BPS East Java, 2013).

The results support the research Langevin and Mendoza (2013); Â-zer and Yilmaz, (2011); Husain (2011); Hobson et al. (2011), which proved that partisipative budgeting may reduce behavioral budgetary slack. This research is aligned with Soobaroyen (2007) states that partisipative budgeting can reduce dysfunctional behavior, but this study does not agree with the results of research Su and Yu-Ni (2013); Breaux et al. (2011) which states that partisipative budgeting is not able to improve the perception on the control slack and performance.

\section{Hypothesis 2 (H2)}

The second hypothesis testing results show that the partisipative budgeting variables have a significant negative effect on gender moderated dysfunctional behavior that is not proven. This is evidenced from the results of statistical test parameter coefficient of 0.8157 with 1.740 statistical value smaller than t-table value of 1.96. The empirical results show that gender is not as moderating variable partisipative budgeting relationship with dysfunctional behavior. However, the relationship indicates the direction of gender roles interact with partisipative budgeting will improve dysfunctional behavior. That is, the subordinate manager in preparing the budget tends to dysfunctional behavior that is synonymous with budgetary slack encouraged action on a conservative budgeting uncertainty high business environment so that performance is maintained properly. It is supported by the phenomenon that the company's medium and large-scale manufacturing in East Java've received awards as a contributor to exports at the national level. Apriwandi empirical studies (2012) and Suhartini et al. (2015) proved that partisipative budgeting improve managerial performance through the behavior of budgetary slack. This condition is triggered by the actions of managers in the face of high uncertainty of business environment in order to maintain their managerial performance. However, these conditions can endanger the sustainability of the company in the long term (Libby and Lindsay, 2007), since managers report performance with conditions that are not true.

In addition, this research proves that the gender roles capable as predictors in reducing dysfunctional behavior. This is evidenced from the results of statistical test parameter coefficient of -0.780 with 2,184 statistical value greater than $t$-table value of 1.96 . These empirical results demonstrate that the role of manager of women and men is a combination of personal character unique and complementary for all the advantages and disadvantages of each character manager for his role as decision makers. Robbins and Judge (2013: 192) states that effective decision making requires a combination of rational analysis and intuition. The opinion was reinforced by scientific findings that human biological elements influenced by the work of the brain lobes, women tend to use intuition analysis, while men use rational analysis. 


\section{Hypothesis 3 (H3)}

The third hypothesis testing results indicate that more female managers behave ethically in preparing the budget is not proven. The results of statistical tests on the female's group showed coefficients of 0.540 parameter with statistical value 1,158 smaller than t-table value of 1.96. However, the relationship indicates the direction of gender roles female groups interact with partisipative budgeting will improve dysfunctional behavior. That is, female managers tend to make conservative dysfunctional behavior driven actions in preparing the budget on condition of environmental uncertainty.

In addition, the results of statistical tests on a group of male showing parameter coefficient 2.819 with a statistical value greater than t-table value of 1.96 . That is, the relationship indicates the direction of gender roles male's groups interact with partisipative budgeting will improve dysfunctional behavior. That is, the male managers tend to dysfunctional behavior driven budgeting conservative measures on the condition of environmental uncertainty. The results of both gender groups between managerial behavior of female and male showed the same behavior in the perception of dysfunctional behavior, but the difference between groups was not statistically significant female while the male group was statistically significant.

The results of this study answers the opinion of Kreitner and Kinicki (2011: 17); Gibson et al. (2012: 92) explains that there are no significant differences in work behavior and managerial skills between male managers and female managers, although there is research which proves that there is a difference when female act more ethical than male. Gulzar and Wang (2011) found that female directors are unlikely to make profit management. Yuhertiana (2011) prove that the head of the female in East Java Province behave more ethically than male heads of agencies. The results of this study are also able to answer the opinion O'Fallon and Butterfield (2005) were ever questioned about the truth that female are more ethical than male in the decision-making context.

\section{Acknowledgement}

\section{Conclusion}

The mechanism of partisipative budgeting is budgeting methods that proved effective in reducing dysfunctional behavior. The budgeting mechanism leads to a positive communication with each other informed as best among subordinate managers under the superior manager as his boss. Subordinate centers would reveal information about their responsibilities and provide the best ideas in formulating the budget, while the superior will be committed to not violate the agreement that was made with a subordinate.

Gender roles are not moderate the effects of partisipative budgeting to dysfunctional behavior, but do show a positive direction. This phenomenon is in line with conservative measures do dysfunctional behavior manager in preparing the budget under conditions of uncertainty increasingly competitive business environment. Therefore, managers must immediately rectify any shortcomings that exist and top management have to respond to the problems wisely. However, gender roles capable as predicted in reducing dysfunctional behavior. This indicates there is a combination of the unique character of masculine and feminine in making the best decision.

The female manager was not shown to behave ethically in preparing the budget. However, the direction of the positive relationship that suggests they do dysfunctional behavior. While male managers there are tendencies dysfunctional behavior in preparing the budget. This phenomenon is explained there were no significant differences in work behavior and managerial skills between 
male managers and female managers, although there is research which proves that there is a difference when female act more ethical than male.

\section{Implications of Research Results}

The results of this study are expected to contribute as additional knowledge in the development of accounting behavioral sciences, especially in the study of management accounting.Also, it should be noted that when talking about budgeting is not just struggling with the amount of numbers alone, but need to be considered personal character that can affect the behavior of the individuals involved in it. In this case, to consider gender diversity in the budget drafting team for decision making requires a unique combination of masculine and feminine characters, such as the combination of rational attitude and intuition. Rational lots owned by male and female-owned intuition. This was triggered by the use of the human brain that is affected lobe psychological aspects.

The results of this study are expected also to contribute ideas in management accounting practices, especially in manufacturing companies in East Java and generally in Indonesia. In this case, more attention to the psychological empowerment of managers, especially in the implementation of partisipative budgeting that gender roles can effectively optimize the performance of the company.

\section{Limitations and Suggestions}

This study has limitations, because it is done on the entire manufacturing medium and large scale in East Java. In fact, each company has a diverse character and problems, resulting in less optimal in the study to generalize. Additionally, the difficulty in classifying data due to lack of availability of valid data on the company's criteria by the relevant agencies.

Future research company suggested using homogeneous samples and showed a good performance. Therefore, it is recommended to use samples of food and beverage company or a furniture company, because the company is currently showing a good performance in East Java. Future research also suggested using another personal character variables, such as selfefficacy and locus of control for this variable is able to act as a moderating or mediating variables that can affect thinking and behavior manager.

\section{References}

[1] M. D. Akers and T. V Eaton, "Underreporting of Chargeable Time: the impact of gender and characteristics of underreporters," J Manag. Issues, vol. 15, no. 1, p. 82, 2003.. Journal ofManageriallssues. Vol. XV. No. 1.82-89.

[2] Apriwandi, "Pengaruh Locus of Control, Budaya Paternalistik, Kapasitas Individu, Terhadap Keefektifan Penganggaran Partisipatif Dan Budgetary Slack Dalam Peningkatan Kinerja Manajerial," J. Kaji. Manaj. Bisnis, vol. 1, no. 2, pp. 109-133, 2012.Atkinson, Anthony A., Robert S. Kaplan, Ella MM and S. Mark Young. 2012. Management Accounting: Information for Decision-Making and Strategy Execution: International Edition, 6th Ed. Pearson Higher Education.

[3] Bakrie, Anindya. N.“APEC 2013 dan Peran Perempuan.” .Http://regional.kompas.com/read/2012/09/17/02081143/.APEC.2013.dan.Peran.Perempua n. . Downloaded dated 23 February, 2013. 
[4] R. Bampton and P. Maclagan, "Does a 'care orientation' explain gender differences in ethical decision making? A critical analysis and fresh findings," Bus. Ethics A Eur. Rev., 2009.

[5] A. Riahi-belkaoui, "Behavioral management accounting," Choice Rev. Online, vol. 39, no. 11, pp. 39-6517-39-6517, 2002.Birnberg, JG, Lawrence Turopolec and S. Mark Young.1983. The Organizational Context of Accounting. Accounting, Organizations and Society, Vol. 8, No. 213, pp. 111-129.

[6] P. J. T. BPS, "Pertumbuhan Produksi Industri Manufaktur Triwulan I Tahun 2013 Jawa Timur," vol. 30/05/35/T, no. Pertumbuhan Produksi Manufaktur Triwulan I, pp. 1-8, 2016.

[7] BPS. East Java. 2013. Press Release BPS East Java Province. In 2013 .Growth in Industrial Production Manufacturing Third Quarter 2013 East Java. No. 73/11/35 / Th.XI, 1.

[8] BPS. East Java. 2016 Press Release BPS East Java Province. Manufacturing Industrial Production Growth Fourth Quarter 2015 East Java. 11/02/35 / Th.XIV. 1Februari 2016.

[9] Breaux, KT, DW Finn, and A. Jones III. 2011. The budgetary Commitment as a mediating Influence. Journal of Managerial Issues . XXIII (4): 426-446.

[10] Broadbridge, A., and Jeff. Hearn. 2008. Gender and Management: New Directions in Research and Continuing Patterns in Practice. British Journal of Management. Vol.19, S38-S49.

[11] Bussey, Kay., And Bandura, Albert. 1999. Social Cognitive Theory of Gender Development and Differentiation. Psychological Review. The American Psychological Association, Inc.Vol. 106, No. 4, 676-713

[12] Carter, William K., and Milton F. Usry. 2002. Cost Accounting . $13^{\text {th }}$ Edition. Thomson Learning.

[13] Ghozali, Imam. 2014. Structural Equation Modeling. Alternative methods With Partial Least Squares (PLS). Body Publisher Diponegoro University, Semarang.

[14] Gibson, JL, John, M.Ivancevich., James. HD ,. and Robert. K. 2012.: Behavior, Structure, Processes. (14th ed) McGraw. Hill

[15] Griffin, RW, and Gregory Moorrhead. 2014 Organizational Behavior. Managing People and Organizations. (11th ed). South-Western.

[16] Gul, FA, C. Min, and B. Srinidhi. 2010. Gender Diversity on US Corporate Boards and Cost of Capital. Working paper, The Hong Kong Polytechnic University.

[17] Gulzar, MA and Wang, Zongjun. 2011. Corporate Governance Characteristics and Earnings Management: Empirical Evidence From Chinese Listed Firms. International Journal of Accounting and Financial Reporting. ISSN 2162-3082. Vol. 1, No. 1.

[18] Hobson, L. Jessen, Mark, JM, and Douglas ES 2011. Determinants of Moral judgments Regarding budgetary Slack: An Experimental Examination of Pay Scheme and Personal Values. Behavioral Research in Accounting . Vol.23. No.1.87-107.

[19] Husain, Walidun. 2011. S tructuralOfficialsâ $€$ тм Connection to and Participation in Budget Drafting. International Journal of Administrative Science \&Organization. Volume 18, No. 3.

[20] Jaworsky, BJ, and S.Mark Young. 1992. Dysfunctional Behavior and Management Control: An Empirical Study of Marketing Managers. Accounting Organizations and Society. Vol. 17.\# 1. pp.17-35.

[21] Kartika, Andi. (2010). Influence of Organizational Commitment and Environmental Uncertainty Relation Between Participation in Budget With budgetary slack (Empirical Study On Private Hospital in Semarang).Study Accounting . Hal: 39-60 Vol. 2 No. 1 ISSN: 1979-4886 
[22] Kail, Robert V. (2007). Children and Their Development . Fourth Edition. Pearson Prentise Hall.

[23] Kmec, JA, and Elizabeth H. Gorman. 2010. Gender and Work Discretionary Effort: Evidence From the United States and Britain. Work and Occupations . 37 (1) 3-36.

[24] Kreitner, R., and Kinicki, A. 2004. Organizational Behavior (6th Ed.). New York: McGraw Hills.

[25] Krishnan, R., E. Marinich, and MD Shields. 2012. participative budgeting, Psychological Contracts, and Honesty of Communication. Social Science Research Networks . 1910226.

[26] Langevin, Pascal and Mendoza, Carla. 2013. How Can Management Control System Fairness Reduce Managers Unethical Behaviours ?. European Management Journal, Vol. 31.Issue 3. 209-222.

[27] Libby, Theresa and R Murray Lindsay. 2007. Beyond Budgeting ?, Or Better Budgeting Strategic Finance . 89.2, 46.

[28] Liza, Noor binti Adnan, CheZuriana, MJ, and MN 2013.Ethical NorAzila antecedents of Dysfunctional Behavior in Performance Measurement and Control System. Asian Social Science ; Vol. 9, No. 1.

[29] Locke, EA, and Schweiger, DM 1979. Participation in Decision Making: One More Look. Research in Organizational Behavior. Greenwich, CT: JAI Press.

[30] Industry magazine, issue 1 of 2013

[31] Mowen, MM, Don R.Hansen., Don L Heirtger. (2014). Cornerstones of Managerial Accounting . Fifth Edition. South-Western Cengage Learning.

[32] Nafarin, M. 2007. Corporate Budgeting. Issue 3. Publisher Salemba Four, Jakarta

[33] Nahartyo, Ertambang. 2013. Participation budgetary And Procedural Justice: Evidence From Stretch Budget Condition. Global Journal of Business Research . Vol.7.No.4.

[34] Nugroho, Riant. 2008. Gender and Utamaannya mainstreaming strategy in Indonesia. Student Library. First edition, Yogyakarta.

[35] Nurhaeni, ISMI Dwi. A. 2010. Public Policy Pro Gender, UPT Publishing and Printing UNS.

[36] Oа $€$ тм Fallon, MJ, and Butterfield, KD 2005. A Review of the Empirical Literature Ethical Decision-Making: 1996a € "2003. Journal of Business Ethics. 59: 4, 375â €" 413.

[37] Ã-zer, Gokhan, danEmineYilmaz. 2011. Effects of Procedural Justice Perception, budgetary Control Effectiveness and Ethical Work on Climate propensity to Create budgetary Slack. Business and Economics Research Journal . Vol. 2 \# 4. pp.1-18.

[38] Robbins, Stephen P and Timothy. A. Judge. 2013. Organizational Behavior, $15^{\text {th }}$ ed. Pearson Education Inc.

[39] SoobaroyenTeerooven. 2007. Management Control System and Dysfunctional Behavior: An Empirical Investigation. A thesis submitted to the University of Wales in partialfulfilment for the degree of Doctor of Philosophy

[40] Srinidhi, Bin ,. Ferdinand. AG, and Judy.T. 2011. Female Directors and Earnings Quality. Contemporary Accounting Research. Vol. 28 No. 5. 1610â $€$ "1644

[41] Su Chin-Chun, and Ni, Feng-Yu. Budgetary 2013. Participation and Slack On The Theory Of Planned Behavior. The International Journal of Organizational Innovation. Vol.5.No.4.

[42] Suhartini, Dwi.,EkoRiadi., And Rida PW 2015 budgetary Slack and Managerial Performance Models: Gender Perspective. European Journal of Business and Management . ISSN 2222-1905 (Paper) ISSN 2222-2839 (Online). Vol.7. 29.

[43] Suki, NorazahMohd., AndNorbayahMohdSuki. 2011. Job Satisfaction and OrganisationalCommitment: The Effect of Gender. International. Journal of Psychology Research .Volume 6, Issue 5, pp. 1-15

[44] Omar, Hussein. 2007. Research Methods For Thesis and Thesis Business, Jakarta: PT. King GrafindoPersada

[45] Wood, Julia. T ,.2007.gendered Lives: Communication, Gender, and Culture $7^{\text {th }}$ Edition. Thomson Wadsworth. 
[46] Yuen, Desmond C. Y. 2007. The antecedents of budgetary Participation: Enhancing Job Performance Employees. Managerial Auditing Journal. Vol. 22 No. 5, pp. 533-548.

[47] Yuhertiana, Indrawati. 2011. A Gender Perspective of budgetary slack in East Java Local Government. International Research Journal of Finance and Economics. ISSN 1450-2887 Issue 78.EuroJournals Publishing. Inc.

[48] Yu-Ni, Feng ,. Chin-Chun Su ,. Shao Chung-Hsi ,. andKuo-Chih Cheng. 2009. The budgetary Participationâ $€$ TM $s$ Managerial Effect on Outcomes: mediating Roles of Self-Efficacy and Attitudes toward budgetary Decision Makers. Http://ebookbrowse.com/ni-su-chung-and-cheng-pdf ._Downloaded dated March 17, 2013 , 